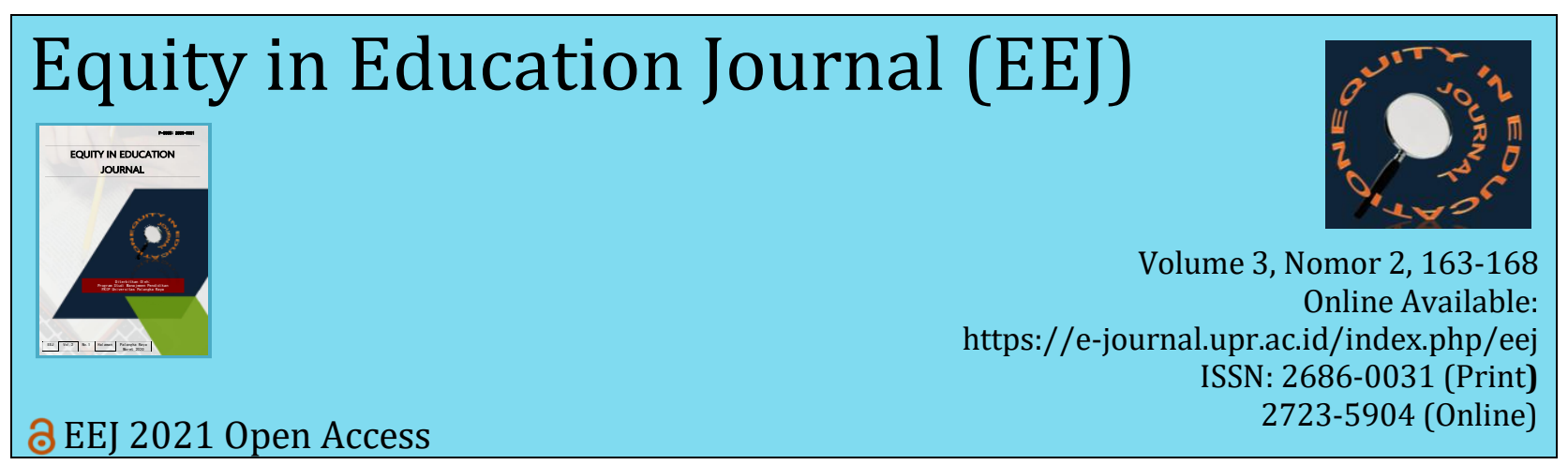

\title{
HUBUNGAN KINERJA GURU TERHADAP PRESTASI BELAJAR SISWA SMA MUHAMMADIYAH 1 PALANGKA RAYA
}

\author{
Muhamat Akbar*, Erenfried Dagau, Dagai L. Limin \\ Universitas Palangka Raya, Palangka Raya
}

\begin{tabular}{|c|c|}
\hline Info Artikel & Abstrak \\
\hline $\begin{array}{l}\text { Diterima: } 23 \text { April } 2021 \\
\text { Direvisi: } 3 \text { Juni } 2021 \\
\text { Disetujui: } 27 \text { Juli } 2021 \\
\text { Kata Kunci: } \\
\text { Kinerja, Guru, Prestasi Belajar } \\
\text { Siswa, SMA Muhammadiyah } 1 \\
\text { Palangka Raya. }\end{array}$ & $\begin{array}{l}\text { Penelitian ini bertujuan mengetahui hubungan antara kinerja guru dengan } \\
\text { prestasi belajar siswa SMA } 1 \text { Muhammadiyah Palangka Raya. Populasi dalam } \\
\text { penelitian ini seluruh guru yang mengajar pada kelas XII IPS II sejumlah } 15 \\
\text { orang, yang selanjutnya ditetapkan sebagai sampel total. Pengumpulan data } \\
\text { menggunakan angket/kuisioner. Analisis data menggunakan korelasi Spearman } \\
\text { dengan bantuan aplikasi IBM SPSS versi 20. Hasil penelitian menunjukkan } \\
\text { bahwa terdapat hubungan antara kinerja guru dengan hasil belajar siswa kelas } \\
\text { XII di SMA } 1 \text { Muhammadiyah Palangka Raya. }\end{array}$ \\
\hline Korespondensi: & Abstract \\
\hline $\begin{array}{l}\text { Muhamat Akbar* } \\
\text { Universitas Palangka Raya } \\
\text { Email: } \\
\text { muhamatakbarbd911@gmail.com }\end{array}$ & $\begin{array}{l}\text { This study aims to determine the relationship between teacher performance and } \\
\text { student achievement at SMA } 1 \text { Muhammadiyah Palangka Raya. The population } \\
\text { in this study were all } 15 \text { teachers who taught in class XII IPS II, which were } \\
\text { then designated as the total sample. Data analysis used Spearman correlation } \\
\text { with the help of the IBM SPSS version } 20 \text { application. The results showed that } \\
\text { there was a relationship between teacher performance and student learning } \\
\text { outcomes in class XII in SMA } 1 \text { Muhammadiyah Palangka Raya. }\end{array}$ \\
\hline
\end{tabular}

\section{PENDAHULUAN}

Melihat perkembangan zaman pada umumnya, pendidikan harus dapat diarahkan dengan upaya pembentukan manusia yang tanggap terhadap perubahan. Disamping itu pendidikan juga harus menyentuh potensi peserta didik sebagai obyek belajar. Nurdin (2008) menyatakan bahwa pendidikan yang baik adalah pendidikan yang mampu memberikan sumbangan pada semua pertumbuhan individu dalam meningkatkan, mengembangkan dan menumbuhkan kesediaan bakat, minat, dan kemampuan akalnya. Dewasa ini dunia Pendidikan berkembang dengan pesat yang mengakibatkan persoalan di ranah pendidikan semakin luas dan kompleks. Persoalan tersebut menjadi sebuah tantangan yang harus kita hadapi agar dapat menyongsong pendidikan yang berkualitas seperti apa yang disebutkan dalam tujuan pendidikan nasional. Melihat persoalan yang semakin kompleks, sudah menjadi tanggung jawab tenaga pendidik untuk mengatasi kendalakendala tersebut agar perkembangan pendidikan menjadi semakin baik dan tercapainya pendidikan yang bermutu. Sanjaya (2006) menyatakan guru sebagai pengajar merupakan pencipta kondisi belajar siswa yang didesain secara sengaja, sistematis dan berkesinambungan, sedangkan anak sebagai subjek pembelajaran merupakan pihak yang menikmati kondisi belajar yang diciptakan seorang guru sehingga proses belajar mengajar melibatkan dua pelaku aktif, yaitu guru dan siswa. 
Perkembangan peserta didik banyak dipengaruhi dan ditentukan oleh bagaimana seorang guru dalam mengajar karena guru memiliki andil yang sangat besar pada kegiatan belajar mengajar di sekolah karena guru menjadi center dalam pembelajaran di kelas. Nurdin (2008) menyatakan pekerjaan guru adalah mendidik. Mendidik ialah suatu usaha yang kompleks, mengingat banyaknya kegiatan yang harus diantisipasi dalam membawa anak didik menjadi orang yang lebih dewasa. Kecakapan mendidik diperlukan agar tujuan pendidikan dapat dicapai semaksimal mungkin. Ini berarti kinerja guru harus benar-benar professional Oleh karena itu, guru harus memiliki kinerja yang tinggi dalam pelaksanaan pembelajaran. Selain itu seorang guru juga perlu memiliki kepribadian, menguasai bahan pelajaran dan menguasai cara-cara mengajar sebagai kompetensinya. Tanpa hal tersebut guru akan gagal dalam melaksanakan tugasnya. Usman (2011) menyatakan proses belajar dan hasil belajar para siswa sebagian besar ditentukan oleh kinerja guru. Kinerja guru yang tinggi/baik akan lebih mampu menciptakan lingkungan belajar yang efektif dan akan lebih mampu mengelola kelasnya, sehingga hasil belajar siswa berada pada tingkat optimal. Prestasi belajar merupakan hasil dari aktivitas belajar atau hasil dari usaha, latihan dan pengalaman yanag dilakukan oleh seseorang, dimana prestasi tersebut tidak akan lepas dari pengaruh faktor luar diri peserta didik (Maesaroh, 2013).

Berdasarkan data tahun 2018, masih banyak guru yang belum memiliki persyaratan kualifikasi pendidikannya. Hal ini akan berdampak pada mutu pendidikan. Apabila tujuan pembelajaran tidak tercapai dengan baik maka akan menghasilkan output yang belum memadai. Program pemerintah seperti sertifikasi dan tunjangan guru akan sia-sia apabila kualitas guru justru semakin menurun. Oleh sebab itu, para profesional (guru) membutuhkan proses belajar (termasuk praktek) yang berkesinambungan (continual), dengan bermacam-macam cara. Mulai dari membaca buku, menganalisa pengalaman orang lain, mengikuti seminar atau diskus, kerja praktek hingga mengikuti program redukasi (retraining) mungkin juga melanjutkan studi ke jenjang yang lebih tinggi (Kunandar, 2007).

Studi Sumantri (2015) menunjukkan bahwa 76,6\% hasil belajar siswa dipengaruhi oleh kinerja guru, dengan rincian kemampuan guru mengajar memberikan sumbangan 32,43\%, penguasaan materi pelajaran memberikan sumbangan $32,38 \%$, dan sikap guru terhadap mata pelajaran memberikan sumbangan $8,60 \%$. Hasil studi tersebut menunjukkan bahwa kinerja guru merupakan faktor penting dalam menentukan kualitas pembelajaran. Tuntutan kinerja guru memiliki tingkatan kesulitan masing-masing pada setiap mata pelajaran. Dari uraian di atas, apabila dikaitkan dengan kinerja guru di SMA Muhammdiyah 1 Palangka Raya berdasarkan observasi yang dilakukan peneliti kepada 15 orang guru yang mengajar di kelas XII baik itu guru mata pelajaran dan wali kelas sudah menunjukan kinerja yang baik hasil ini di peroleh dari Penilaian Kinerja Guru (PKG) pada tahun 2019/2020 yang menunjukan nilai rata-rata guru yaitu sebanyak 70 dan nilai tertinggi berada di 77 dan nilai terendah 63 dari 15 orang guru yang mengajar di kelas XII. Disamping itu sesuai pengamatan peneliti dalam hal melaksanakan kegiataan proses belajar mengajar di kelas juga sudah baik, para guru juga sudah memiliki kelengkapan perangkat pembelajaran, cukup terampil dalam penggunaan media pembelajaran, serta tingkat kedisplinan guru juga sudah baik. Prestasi belajar siswa pada tahun ajaran 2019/2020 juga menunjukan hasil yang baik dengan nilai rata-rata siswa sebesar 86, nilai tertinggi sebesar 90 dan nilai terendah sebesar 80 dari 24 siswa kelas XII IPS II di SMA Muhammadiyah 1 Palangka Raya. Berdasarkan fenomena tersebut dapat diasumsikan bahwa kinerja guru yang baik berhubungan dengan prestasi belajar siswa.

Penelitian ini bertujuan untuk mengetahui hubungan kinerja guru dengan prestasi belajar siswa kelas XII IPS II di SMA Muhammadiyah 1 Palangka Raya.

\section{METODE}

Penelitian ini merupakan penelitian kuantitatif korelasional. Pendekatan kuantitatif bertujuan untuk menguji teori, membangun fakta menunjukkan hubungan antar variabel, memberikan deskripsi statistik, menaksir dan meramalkan hasilnya (Sarwono, 2009). Dengan kata 
lain, dalam penelitian kuantitatif peneliti berangkat dari paradigma teoritik menuju data, dan berakhir pada penerimaan atau penolakan terhadap teori yang digunakan. Berdasarkan jenis permasalahan dalam penelitian ini, penelitian ini merupakan penelitian korelasional bertujuan untuk melihat sejauh mana variabel pada satu faktor berkaitan dengan variasi-variasi pada satu atau lebih faktor lain. Populasi dalam penelitian ini seluruh guru yang mengajar pada kelas XII IPS II sejumlah 15 orang, yang selanjutnya ditetapkan sebagai sampel total. Data prestasi belajar siswa kelas XII IPS II menggunakan nilai rapor siswa yang diperoleh dari guru wali kelas masingmasing. Analisis data menggunakan korelasi Spearman dengan bantuan aplikasi IBM SPSS versi 20 .

\section{HASIL DAN PEMBAHASAN Uji Validitas}

Validitas adalah suatu ukuran yang menunjukkan tingkat-tingkat kesahihan suatu instrumen. Sebuah instrumen dikatakan valid apabila mampu mengukur apa yang di inginkan dan dapat mengungkap data dari variabel yang diteliti secara tepat. Dalam melakukan pengujian validitas instrumen peneliti menggunakan Microsoft Excel 2010. Instrumen dianggap valid dilakukan dengan membandingkan dengan nilai tabel koefisien Spearman. Jika nilai $r$ hitung $>$ koefisien Spearman (Nilai $r$ tabel) dengan taraf signifikan 5\% maka instrumen dikatakan valid.

Tabel 1. Uji Validitas Angket Kinerja Guru

\begin{tabular}{cccc}
\hline No. Butir Instrumen & Nilai r Hitung & Nilai r Tabel & Keterangan \\
\hline 1. & 0.368689382 & 0.266 & VALID \\
2. & 0.633697834 & 0.266 & VALID \\
3. & 0.556219762 & 0.266 & VALID \\
4. & 0.684952759 & 0.266 & VALID \\
5. & 0.625740046 & 0.266 & VALID \\
6. & 0.613104885 & 0.266 & VALID \\
7. & 0.559388847 & 0.266 & VALID \\
8. & 0.296268243 & 0.266 & VALID \\
9. & 0.625740046 & 0.266 & VALID \\
10. & 0.572675494 & 0.266 & VALID \\
11. & 0.740758114 & 0.266 & VALID \\
12. & 0.283581884 & 0.266 & VALID \\
13. & 0.406941142 & 0.266 & VALID \\
14. & 0.641839657 & 0.266 & VALID \\
15. & 0.499424543 & 0.266 & VALID \\
16. & 0.567220409 & 0.266 & VALID \\
17. & 0.381030492 & 0.266 & VALID \\
18. & 0.591078015 & 0.266 & VALID \\
19. & 0.648758716 & 0.266 & VALID \\
20. & 0.505144629 & 0.266 & VALID \\
21. & 0.567220409 & 0.266 & VALID \\
22. & 0.522582402 & 0.266 & VALID \\
23. & 0.373107739 & 0.266 & VALID \\
24. & 0.352186619 & 0.266 & VALID \\
25. & 0.633303335 & 0.266 & VALID \\
26. & 0.593986124 & 0.266 & VALID \\
27. & 0.373107739 & 0.266 & VALID \\
28. & 0.483368429 & 0.266 & VALID \\
29. & 0.527762698 & 0.266 & VALID \\
30. & 0.677107909 & 0.266 & VALID \\
\hline & & & \\
\hline & & &
\end{tabular}

Berdasarkan Tabel 1. di atas dengan jumlah butir instrumen sebanyak 30 pertanyaan dan jumlah responden sebanyak 57, maka nilai koefisien Spearman dengan taraf signifikan 5\% 
dikatakan valid apabila hasil $r$ hitung $>0.266$. Dari kesimpulan dalam Tabel 1. di atas, menunjukan bahwa nilai $r$ tabel rata-ratanya memiliki nilai lebih besar dari $r$ hitung, sehingga setiap butir instrumen layak digunakan dalam penelitian.

\section{Uji Reliabilitas}

Reliabilitas mengandung pengertian bahwa suatu instrument dapat dipercaya untuk digunakan sebagai pengumpul data karena instrumen tersebut sudah baik. Peneliti menggunakan IBM SPSS Statistic 20 sebagai alat ukur. Reliabilitas instrumen diperlukan untuk mendapatkan data sesuai dengan tujuan pengukuran. Untuk mencapai hal tersebut, dilakukan uji reliabilitas dengan menggunakan metode Alpha Cronbanch diukur berdasarkan skala Alpha Cronbanch sampai 1. Perhitungan reliabilitas instrumen dilakukan dengan bantuan SPSS versi 20. Sujarweni (2014) menyatakan kuisioner dinyatakan reliabel jika Cronbach Alpha > 0,6. Berdasarkan hasil analisis diperoleh hasil uji reliabilitas instrumen penelitian sebagai berikut:

\section{Tabel 2. Uji Hasil Reabilitas Angket Kinerja Guru Reliability Statistics \\ Cronbach's Alpha $\mathrm{N}$ of Items \\ .890 30}

Berdasarkan nilai koefisien realibilitas (Alpha Cronbach) angket kinerja guru sebagai variabel $(\mathrm{X})$ dengan nilai 0,890 yang mana berada pada kelas sangat reliable yang berada pada nilai 0,81 - 1,00; sehingga disimpulkan nilai Alpha tersebut termasuk ke dalam kriteria tingkat kepercayaan yang sangat tinggi dan sangat reliabel untuk digunakan dalam pengambilan data, karena berdasarkan nilai Alpha Cronbach > 0,6 yang berarti data penelitian dapat dikatakan reliabel.

\section{Uji Normalitas}

Uji Normalitas data yang dilakukan tiap masing-masing data dengan tujuan untuk mengetahui apakah data tersebut berasal dari populasi distribusi normal atau tidak. Untuk uji normalitas menggunakan one-sample kolmogorov-smirnov test pada program IBM SPSS Statistic 20 dengan taraf signifikasi $\alpha=0,05$.

Tabel 3. Uji Hasil Normalitas

One-Sample Kolmogorov-Smirnov Test

\begin{tabular}{|c|c|c|c|}
\hline & & $\begin{array}{c}\text { Kinerja } \\
\text { Guru }\end{array}$ & $\begin{array}{c}\text { Prestasi Belajar Siswa } \\
\text { Kelas XII IPS II }\end{array}$ \\
\hline \multirow[t]{2}{*}{$\mathrm{N}$} & & 57 & 57 \\
\hline & Mean & 114.91 & 82.98 \\
\hline Normal Parameters ${ }^{\mathrm{a}, \mathrm{b}}$ & $\begin{array}{l}\text { Std. } \\
\text { Deviation }\end{array}$ & 13.263 & 4.299 \\
\hline \multirow{3}{*}{$\begin{array}{l}\text { Most Extreme } \\
\text { Differences }\end{array}$} & Absolute & .101 & .076 \\
\hline & Positive & .101 & .068 \\
\hline & Negative & -.058 & -.076 \\
\hline Kolmogorov-Smirnov Z & & .759 & .576 \\
\hline Asymp. Sig. (2-tailed) & & .611 & .894 \\
\hline
\end{tabular}

Kriteria pengambilan keputusan yaitu: jika signifikansi $>0,05$ maka data berdistribusi normal, dan jika signifikansi < 0, 05 maka data tidak berdistribusi normal. Dari hasil perhitungan uji normalitas yang telah dilakukan di atas dapat ditarik kesimpulan sebagai berikut: (1) Kinerja Guru memiliki nilai signifikansi Asymp. Sig. (2-Tailed) 0,611>0.266 maka distribusi normal; (2) Prestasi Belajar Siswa Kelas XII IPS II memiliki nilai signifikansi Asymp. Sig. (2-Tailed) $0,894>0,266$, maka distribusi data normal. Dari pengujian normalitas di atas dapat ditarik 
kesimpulannya bahwa dalam uji persyaratan terpenuhi dengan melihat kelayakan distribusi dari kedua variabel normal.

\section{Uji Hipotesis}

Teknik analisis data yang digunakan dalam penelitian ini adalah dengan uji korelasi rank Spearman. Untuk mengetahui tingkat atau derajat keeratan hubungan antar variabel-variabel yang diteliti, digunakan tabel kriteria pedoman untuk koefisien korelasi. Hipotesis dalam penelitian ini yaitu H0: Tidak ada hubungan antara kinerja guru dengan prestasi belajar siswa kelas XII IPS II di SMA Muhamadiyah 1 Palangka Raya, dan Ha: Ada hubungan antara kinerja guru dengan prestasi belajar siswa kelas XII IPS II di SMA Muhamadiyah 1 Palangka Raya. Hasil Pengujian hipotesis menggunakan IBM SPSS Statistic 20 dengan korelasi rank Spearman disajikan sebagai berikut:

Tabel 4. Hasil Uji Hipotesis Penelitian

Correlations

\begin{tabular}{|c|c|c|c|c|}
\hline & & & Kinerja Guru & $\begin{array}{c}\text { Prestasi Belajar Siswa } \\
\text { Kelas XII IPS II }\end{array}$ \\
\hline \multirow{6}{*}{$\begin{array}{l}\text { Spearman's } \\
\text { rho }\end{array}$} & \multirow{3}{*}{ Kinerja Guru } & $\begin{array}{l}\text { Correlation } \\
\text { Coefficient }\end{array}$ & 1.000 & .880 \\
\hline & & Sig. (2-tailed) & & .228 \\
\hline & & $\mathrm{N}$ & 57 & 57 \\
\hline & \multirow{3}{*}{$\begin{array}{l}\text { Prestasi } \\
\text { Belajar Siswa } \\
\text { Kelas XII }\end{array}$} & Correlation & .880 & 1.000 \\
\hline & & Sig. (2-tailed) & .228 & \\
\hline & & $\mathrm{N}$ & 57 & 57 \\
\hline
\end{tabular}

Sebelum diambil kesimpulan perlu diketahui beberapa hal berikut: apabila nilai signifikansi $<0,05$ maka hipotesis (H0) ditolak dan hipotesis (Ha) diterima, yang berarti terdapat hubungan antar variabel yang diteliti, begitu juga sebaliknya. Berdasarkan hasil analisis data di atas, didapatkan nilai signifikansi antara kinerja guru dengan prestasi belajar siswa kelas XII IPS II sebesar 0,228 yang berarti nilai signifikansi tersebut $<0,266$, sehingga dapat bermakna hipotesis (H0) ditolak dan hipotesis (Ha) diterima, artinya terdapat hubungan kinerja guru dengan prestasi belajar siswa kelas XII IPS II di SMA Muhammadiyah 1 Palangka Raya. Untuk mengetahui arah hubungan (hubungan yang positif atau hubungan negatif) dapat dilakukan dengan melihat tanda pada nilai koefisien korelasi, yaitu positif atau negatif. Jika positif (berbanding lurus) berarti terdapat hubungan yang positif, sebaliknya jika tandanya negatif (berbanding terbalik) maka hubungan keduanya negatif. Berdasarkan hasil dari uji hipotesis penelitian dari data-data yang telah disajikan di atas, maka dapat ditentukan arah hubungan antara kinerja guru dengan prestasi belajar siswa kelas XII IPS II SMA Muhammadiyah 1 Palangka Raya adalah positif, karena didapatkan koefisien korelasi sebesar $+0,880$. Dengan koefisien korelasi juga dapat ditentukan kekuatan korelasi (r) yang menginterpretasikan seberapa kuat hubungan yang ditimbulkan antara kedua variabel pada penelitian. Koefisien korelasi pada hasil uji penelitian ini berada pada rentang kekuatan korelasi yang sangat kuat, yaitu antara 0,80-0,1000. Dengan demikian maka dapat disimpulkan bahwa H0 ditolak dan Ha diterima. Artinya ada hubungan signifikan yang cukup dan searah antara kinerja guru dengan prestasi belajar siswa kelas XII IPS II SMA Muhammadiyah 1 Palangka Raya.

Temuan penelitian yang mengungkap hubungan antara kinerja guru dan prestasi siswa ini sejalan dengan hasil studi Suayib (2020) menyatakan kinerja guru merupakan salah satu faktor yang mempengaruhi prestasi belajar siswa. Yusmiati (2019) menyatakan guru merupakan komponen yang paling berpengaruh terhadap terciptanya proses dan hasil pendidikan yang berkualitas. Oleh karena itu upaya perbaikan apapun yang dilakukan untuk meningkatkan kualitas pendidikan tidak akan memberikan 
sumbangan yang signifikan tanpa di dukung oleh guru yang profesional dan berkualitas. Guru benar- benar di tuntut untuk memiliki kinerja yang tinggi. Seorang tenaga pendidik yang memiliki performance yang baik maka akan mempunyai kinerja yang optimal dalam memberikan pembelajaran terhadap peserta didik, artinya sebagai tenaga pendidik dapat melaksanakan dan melakukan perencanaan pembelajaran, pelaksanaan pembelajaran atau pengelolaan pembelajaran, serta evaluasi pembelajaran dengan baik sesuai dengan ketentuan kurikulum sekolah yang berlaku. Kemudian dengan demikian, maka akan memberikan hasil belajar yang baik bagi peserta didiknya berdasarkan kemampuan masingmasing individu.

\section{SIMPULAN}

Berdasarkan hasil penelitian dan pembahasan dapat disimpulkan bahwa terdapat hubungan antara kinerja guru dengan hasil belajar siswa kelas XII IPS II SMA 1 Muhammadiyah Palangka Raya. Hal ini dibuktikan dengan nilai signifikansi $0,228<0,266$ nilai $r$ tabel singnifikansi 0,05 yang bermakna hipotesis Ha di terima, yang berarti jika kinerja guru tinggi, maka prestasi belajar siswa juga tinggi.

\section{UCAPAN TERIMA KASIH}

Ucapan terima kasih penulis sampaikan kepada pihak Kepala Sekolah, Wali kelas beserta Bapak/Ibu guru dan siswa kelas XII IPS II SMA Muhammadiyah 1 Palangka Raya yang telah memberikan ijin dan kemudahan selama proses penelitian ini berlangsung, serta Redaksi Equity in Education Journal (EEJ) yang telah memberikan kesempatan artikel penulis dapat dimuat dalam jurnal ini.

\section{DAFTAR PUSTAKA}

Kunandar. (2007). Guru Professional: Implementasi KTSP dan Sukses dalam Sertifikasi Guru. Jakarta: Raja Grafindo Persada.

Maesaroh, S. (2013). Peranan Metode Pembelajaran Terhadap Minat dan Prestasi Belajar Pendidikan Agama Islam. Jurnal Kependidikan, 1(1).

Nurdin, M. (2008). Kiat menjadi Guru Profesional. Jogjakarta: Ar-Ruzz Media.

Sanjaya, W. (2006). Pembelajaran dalam Implementasi Kurikulum Berbasis Kompetensi. Jakarta: Kencana.

Sarwono, J. (2009). Memadu Pendekatan Kuantitatif dan Kualitatif: Mungkinkah?. Jurnal Ilmiah Manajemen Bisnis, 9(2).

Suayib, L., Anas, M., \& Arisona. (2020). Hubungan Kinerja Guru dengan Hasil Belajar Fisika Siswa SMA se Kota Kendari. Jurnal Penelitian Pendidikan Fisika, 5(2).

Sujarweni, V. W. (2014). Metode Penelitian: Lengkap, Praktis, dan Mudah Dipahami. Yogyakarta: Pustaka Baru Press.

Sumantri, K. (2015). Kompetensi, Profesional Guru Agama Islam dalam Meningkatkan Belajar Siswa di SMK Negeri 1 Bandung Tulungagung Tahun Ajaran 2014-2015. Diterima dari http://repo.iain-tulungagung.ac.id/3163/.

Usman, M. U. (2011). Menjadi Guru Profesional. Bandung: Remaja Rosdakarya.

Yusmiati. (2019). Hubungan Antara Kinerja Guru dan Prestasi Belajar Peserta Didik Pada Mata Pelajaran Pkn Kompetensi Dasar Hakikat Demokrasi Kelas VIII SMP Negeri 8 Padangsidimpuan. Nusantara: Jurnal Ilmu Pengetahuan Sosial, 6(1). 